\title{
Seismic loss assessment of seismically isolated buildings designed by the procedures of ASCE/SEI 7-16
}

\author{
Shoma Kitayama ${ }^{1}$ (D) $\cdot$ Huseyin Cilsalar ${ }^{2}$ (D)
}

Received: 8 February 2021 / Accepted: 29 October 2021 / Published online: 16 November 2021

(c) The Author(s) 2021

\begin{abstract}
This paper investigates the seismic loss assessment of seismically isolated and non-isolated buildings with steel moment or braced frames, designed by the seismic design standard of ASCE/SEI 7-16. The seismic loss is calculated from the damage to structural and nonstructural components, as well as the demolition and the collapse of buildings. This study demonstrates that the expected annual losses for seismically isolated buildings are half or less than half of those calculated for non-isolated buildings. These losses depend on the types of seismic isolation systems and seismic force resisting systems used. Among the cases of isolated buildings studied in this paper, the most cost-effective systems are found to be the buildings designed by minimum strength requirement in ASCE/SEI 7-16 and with isolators which have displacement capacity 1.5 times larger than the minimum required in ASCE/SEI 7-16, in terms of expected annual losses. This study also compares the results obtained from different approaches of selection and scaling of ground motions. The following research finds that when Incremental Dynamic Analysis approach with far-field ground motion set in FEMA P695 is used, the computed expected total annual losses become doubled from the Conditional Spectra approach.
\end{abstract}

Keywords Seismic loss assessment · Seismic isolation · ASCE/SEI 7 standard · Friction pendulum isolator $\cdot$ Displacement restraint $\cdot$ Collapse probability

\section{Background}

Previous studies by first author (Kitayama and Constantinou 2018a, 2019a) and others (Shenton and Lin 1993; Masroor and Mosqueda 2015; Sayani et al. 2011; Erduran et al. 2011) demonstrated that the seismic performance of seismically isolated buildings is superior to that of comparable non-isolated buildings in terms of reduced seismic demands, such as reduced floor acceleration, reduced peak story drift and reduced residual story

Shoma Kitayama

s.kitayama@leeds.ac.uk

Huseyin Cilsalar

huseyin.cilsalar@bozok.edu.tr

1 School of Civil Engineering, University of Leeds, Leeds LS2 9JT, UK

2 Department of Civil Engineering, Yozgat Bozok University, Yozgat, Turkey 
drift. Other studies (Kitayama and Constantinou, 2018b, 2019b; Bao et al. 2018) demonstrated that increasing the displacement capacity of seismic isolation system or having moat wall with higher design strength of isolated superstructures could reduce the collapse probability and achieve the acceptable collapse probability defined by ASCE 7 seismic design standards (ASCE 2010, 2017).

The above studies demonstrated that the seismically isolated buildings could be designed to achieve higher performance than those comparable non-isolated buildings under wide range of earthquake events. However, some owners of buildings, especially those who own structures whose failure would not inhibit the availability of essential community services in an emergency situation (those belong to Risk Category IV in ASCE/SEI 7-16, 2017), may still choose non-isolated buildings because the initial costs of seismically isolated buildings are generally higher than those of comparable non-isolated buildings. A building owner is generally motivated by cost, and higher initial cost of a seismically isolated building coupled with the difficulty of conveying the seismic performance benefits have prevented seismic isolation from becoming mainstream design practice in the United States (Ryan et al. 2010; Cilsalar 2019). While the seismic performance enhancement by using seismic isolation systems would likely increase the initial cost, it is expected that this increase might be compensated by benefits realized over the life of a structure (Terzic et al. 2012). To encourage the implementation of seismic isolation systems to a wider class of structures, earthquake engineering professionals must be able to demonstrate those situations when the seismic isolation represents more appropriate and cost-effective earthquake risk management (Cutfield et al. 2016).

One of the earliest studies of life cycle performance of seismically isolated buildings was conducted by Thiel (1986). The study examined the different structural systems of superstructures, disruption values, insurance coverage deductible, insurance cost, different regions, and lifetime of structures. The study concluded that base isolation is an economically attractive option compared to other non-isolated structures while the level of economic advantage of using seismic isolation has strong dependence on insurance parameters and disruption costs.

Pyle et al. (1993) performed a life cycle cost assessment of three different seismic retrofit strategies (seismically isolated structure, and two non-isolated structures) for the State of California Justice Building. The results demonstrated that the life cycle costs of the isolated and non-isolated building (designed by minimum seismic requirements in State of California Seismic Safety Commission 1991) were approximately the same because of the nearly equal balance between the additional cost of special construction for the seismic isolation and its net savings in earthquake losses over the life of the buildings. Note that while the research and practice that followed often overlooked the life cycle cost when assessing the seismic performance of seismically isolated buildings, Pyle et al.'s paper claims that Senate Bill 920 (passed by the State of California in 1989), recognized the importance of life cycle cost rather than simply initial cost.

Recently, Goda et al. (2010) investigated the seismic performance of seismically isolated and non-isolated buildings by using simple 2-DOF and 1-DOF models, respectively. The study demonstrated that the expected lifecycle cost for seismically isolated buildings could be lowered by optimizing the strength of the superstructures. The study concluded that the expected life cycle cost for seismically isolated buildings could be reduced by $20-40 \%$ by comparisons with non-isolated buildings when their design base shear strength values were the same. In practice, the structural strengths of isolated superstructure and non-isolated structure may be different (Kikuchi et al. 2008), and more realistic comparisons of lifecycle costs between isolated and non-isolated buildings are needed. 
More recent studies used PACT software that can implement the seismic loss assessment based on the procedures that are detailed in FEMA P58 (2018). Cutfield et al. (2016) investigated the life cycle performance of non-isolated buildings with Special Concentrically Braced Frames (SCBF) and seismically isolated buildings with Ordinary Concentrically Braced Frames (OCBF). The study found that the performance of isolated buildings was governed by the potential for moat wall pounding. The study also concluded that the cost-efficiency of using seismic isolation systems increases markedly if the increase of initial cost by adding seismic isolation system is $2-3 \%$ of total building construction cost. Sani et al. (2017) studied the seismic performance of low-rise buildings with Special Moment Resisting Frames (SMF) with lead rubber seismic isolation bearings. The study concluded that the increased initial construction cost of seismically isolated buildings in comparison with non-isolated buildings can be repaid within 7-41 years, depending on the assumed discount rate and number of stories of buildings (4, 6 and 8 stories). The study also presented that as the story number increases, the payoff time decreases, moreover, as discount rate increases, payoff time increases. A similar approach was utilized in Ryan et al. (2010), which studied seismic performance of seismically isolated buildings with Intermediate Moment Resisting Frame (IMRF) and OCBF, and non-isolated buildings with SCBF and SMF. The study concluded that the annual losses in the seismically isolated buildings with OCBFs was about $25 \%$ of those with non-isolated buildings with SCBF, however, the annual losses in the seismically isolated buildings with IMRF and non-isolated buildings with SMF were about the same. The study also pointed out that the possible cost premium of $8-12 \%$ for use of seismic isolation systems was deterrent for most owners and the investigation to reduce such amount of premium was needed. Mayes et al. (2013) studied the seismic performance of buildings with various seismic protective systems. The study demonstrated that the seismically isolated buildings with braced frames performed best in comparisons with buildings with moment frames and viscous dampers, Buckling Restrained Braced Frames, SMF, Pres-Lam timber coupled-walls and cast-inplace reinforced concrete shear wall, in terms of calculated repair costs and repair times under the earthquake scenario of 10\% in 50 years occurrence. Dong and Frangopol (2016) studied seismic performance of seismically isolated building with IMRFs and non-isolated buildings with SMFs. Their investigation examined various seismic performance indexes, including repair loss, fatality loss, $\mathrm{CO}_{2}$ emissions and downtime. The study concluded that the seismic performance of seismically isolated buildings was superior to that of comparable non-isolated buildings.

\section{Reserch scope}

While the aforementioned studies provided some insights into the life cycle seismic loss performance of seismically isolated buildings, there are more things that should be considered. Namely, some studies did not consider the displacement capacity of seismic isolation bearings (Goda et al. 2010; Terzic et al. 2012; Mayes et al. 2013; Dong and Frangopol 2016); other studies did not employ large number of recorded seismic ground motions to consider the effect record-to-record variability on the results of assessment (Goda et al. 2010; Dong and Frangopol 2016). Also, none of the studies considered the contribution from residual story drift to the seismic loss calculation, which was found to be significant for non-isolated reinforced concrete buildings by previous study (Ramirez and Miranda 2012). In addition, some of the above studies (Ryan et al. 2010; Terzic et al. 
2012; Dong and Frangopol 2016; Cutfield et al. 2016) studied seismically isolated buildings that were designed based on the previous design standard (ASCE/SEI 7-10 2010) that required smaller minimum design strength for isolated superstructures than the required strength specified in the latest standard (ASCE/SEI 7-16 2017). The study of the isolated buildings that are designed by different design standards (ASCE/SEI 7-10 or ASCE/SEI 7-16) resulted in different seismic performance in terms of peak story drift, peak residual drift, peak floor acceleration and collapse probability (Kitayama and Constantinou 2018a, 2019a). Finally, none of the above studies considered appropriate set of ground motion records for nonlinear seismic response analysis that are representative of various intensities of earthquake events in terms of the acceleration response spectra shapes (Baker and Cornel 2006). The study reported in this paper attempts to address the issues above that have not yet been addressed.

This study investigates the seismic loss in terms of repair costs of structural and non-structural components and cost that arises when demolition is needed and collapse occurs in seismically isolated and non-isolated buildings with SCBFs and SMFs. The 6-story steel buildings in Kitayama and Constantinou (2018a, b; 2019a, b) are considered. The building plan and elevations are shown in Fig. 1. All buildings considered in this paper were designed based on the requirements in ASCE/SEI 7-16 standard (2017). The design and modeling details of seismically isolated and non-isolated buildings are available in Kitayama and Constantinou (2018a, b; 2019a, b). The data from the results of seismic response analysis in Kitayama and Constantinou (2018a, b; 2019a, b) are used in this paper to compute seismic losses. This study first examines the seismic loss by constructing the loss vulnerability curves for structural repair loss, non-structural repair loss, demolition loss and collapse loss and total loss based on the methodologies developed by Ramirez and Miranda (2012) that explicitly considers the influence of residual story drift. The selection and scaling of ground motions are conducted based on NIST (2011) and Lin et al. (2013) to consider properly the spectral shape effect (Baker and Cornel 2006). Subsequently, the expected annual losses are calculated by integrating the seismic hazard curves with the obtained loss vulnerability curves. Finally, the

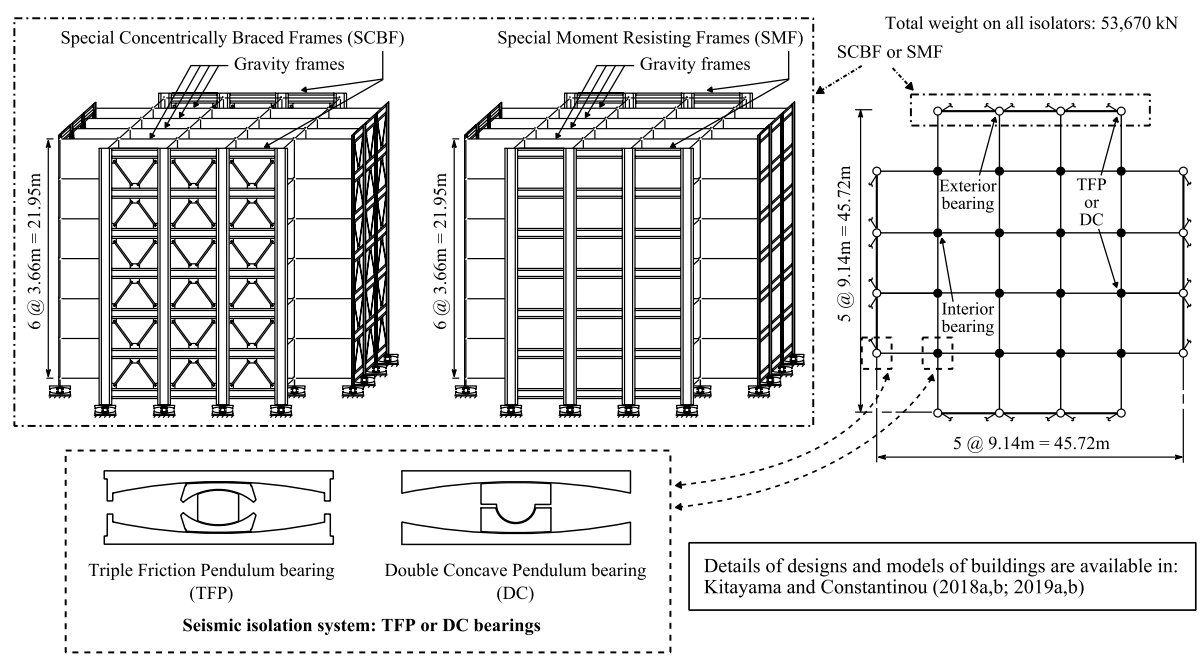

Fig. 1 Building plan and elevations of braced and moment frames 
effect of different methods of selection and scaling of ground motions on the calculated mean annual seismic losses is examined.

\section{Methodology for seismic loss performance assessment}

\subsection{Overview}

This study follows the seismic loss estimation methodology described in Hwang and Lignos (2017a; b) which is based on the study by Ramirez and Miranda (2012). In this study, spectral shape effect is properly accounted for by using Conditional Spectra for selection and scaling of earthquake ground motions for seismic response analysis based on NIST (2011) and Lin et al. (2013). The spectral shape effect on the seismic performance of seismically isolated and non-isolated buildings was found to be significant when computing collapse probability (Haselton et al. 2011; Kitayama and Constantinou 2018a, 2019b; Cilsalar and Constantinou 2020) and thus it may have an important effect on the seismic loss estimation. More information regarding the ground motion selection and scaling for the structures studied in this paper can be found in Kitayama and Constantinou (2018a). As an example, selected and scaled ground motions for seismic response analysis of seismically isolated buildings, target Conditional Spectra (NIST 2011, and Lin et al. 2013) with target variations of $\pm 2 \sigma$, and Conditional Mean Spectra (CMS; Baker 2011) for ten return periods are shown in Fig. 2. Note that the engineering demand parameters (EDP; such as maximum story drift ratios, residual story drift ratios and peak floor accelerations and collapse capacities) that were reported in Kitayama and Constantinou (2018a, b; 2019a, b) are used in this paper.
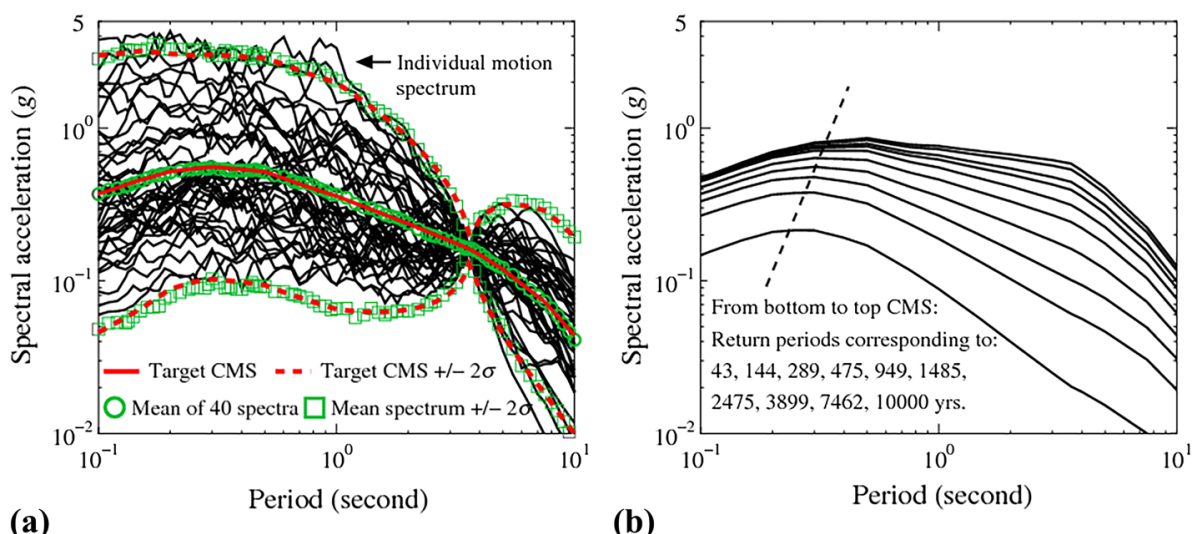

Fig. 2 Example seismic response spectra for selection and scaling of ground motions for response history analysis of seismically isolated buildings with lower bound isolator properties $(\mathrm{T}=3.66 \mathrm{~s})$. a Conditional spectrum with ground motions selected and scaled to fit the target spectrum, b conditional mean spectra (CMS) for different return periods 


\subsection{Formulas}

By assuming mutually exclusive and collectively exhaustive events of building collapse and no collapse, and building demolition and no demolition, the mean of total seismic losses conditioned on the seismic intensity measure $\mathrm{IM}=i m, \mu_{L_{\mathrm{T}} \mid \mathrm{IM}}$, can be written as follow (Hwang and Lignos, 2017a):

$$
\mu_{L_{T} \mid \mathrm{IM}}=\mu_{L_{R} \mid R, \mathrm{IM}, \mathrm{NC}} \cdot\left(1-P_{D \mid \mathrm{IM}, \mathrm{NC}}\right) \cdot\left(1-P_{C \mid \mathrm{IM}}\right)+\mu_{L_{D} \mid \mathrm{D}} \cdot P_{D \mid \mathrm{IM}, \mathrm{NC}} \cdot\left(1-P_{C \mid \mathrm{IM}}\right)+\mu_{L_{C} \mid \mathrm{C}} \cdot P_{C \mid \mathrm{IM}}
$$

where $\mu_{L_{\mathrm{R}} \mid R, \mathrm{IM}, \mathrm{NC}}$ is mean of losses because of repairs for structural and nonstructural components conditioned on no collapse and no demolition given a seismic intensity $\mathrm{IM}=\mathrm{im}$; $\mu_{L_{\mathrm{D}} \mid D}$ is mean of losses due to the demolition. Based on Hwang and Lignos (2017b), $\mu_{L_{\mathrm{D}} \mid D}$ is assumed to be equal to the total replacement cost of the building. This includes the total replacement cost of the building plus additional costs due to building demolition and debris removal $(=10 \%$ of the replacement cost based on Baradaran Shoraka et al. 2013) minus the corresponding cost of those building components that can be recycled $(=10 \%$ of the replacement cost based on Hwang and Lignos $2017 \mathrm{~b}$ ). $\mu_{L_{\mathrm{C}} \mid \mathrm{C}}$ is mean value of loss due to collapse. This loss corresponds to the total replacement cost of the building (Hwang and Lignos 2017b). Given that this paper is discussing fairly modern structures (designed based on ASCE/SEI 7-16, 2017) that are not prone to the progressive, pancake collapse (a collapse mechanism that was often observed in the past—see Okada and Takai 2000; Adam et al. 2018), the "collapse" that we consider in this paper is actually closer to a demolition rather than an outright destruction of the building. Note that, in the end, when building is demolished, adding $10 \%$ of the replacement cost to the total replacement cost of the building and then removing it for recycling brings us to the same values between $\mu_{L_{\mathrm{D}} \mid D}$ and $\mu_{L_{\mathrm{C}} \mid \mathrm{C}} \cdot P_{D \mid \mathrm{IM}, \mathrm{NC}}$ is probability that the building is demolished given an IM=im; $P_{C \mid \mathrm{IM}}$ is collapse probability given an $\mathrm{IM}=i m . \mu_{L_{\mathrm{R}} \mid R, \mathrm{IM}, \mathrm{NC}}$ can be calculated as follows:

$$
\mu_{L_{\mathrm{R}} \mid R, \mathrm{IM}, \mathrm{NC}}=\sum_{i=1}^{m} \sum_{j=0}^{n} \int_{0}^{\infty} \mu_{L_{i j} \mid \mathrm{DS}_{i j}} P_{\mathrm{DS}_{i j} \mid \mathrm{EDP}} f_{\mathrm{EDP} \mid \mathrm{IM}} d \mathrm{EDP}
$$

where $m$ is number of damageable components being considered; $n$ is number of damage states a component may experience; $\mu_{L_{i j} \mid \mathrm{DS}_{i j}}$ is mean repair cost for the $i^{\text {th }}$ component being in the $j^{\text {th }}$ damage state; $f_{\mathrm{EDP} \mid \mathrm{IM}}$ is probability density function of the EDP given an IM $=i m$; $P_{\mathrm{DS}_{i j} \mid \mathrm{EDP}}$ is probability of the EDP of interest associated with the $i^{\text {th }}$ component being the $j^{\text {th }}$ damage state given an $\mathrm{EDP}=e d p$. Note that $f_{\mathrm{EDP} \mid \mathrm{IM}}$ is assumed to follow a lognormal distribution defined by the median and logarithmic standard deviation. The $P_{\mathrm{DS}_{i j} \mid \mathrm{EDP}}$ is calculated by the following equation that can consider dependence of geometry of braces on component fragility curves as (Hwang and Lignos, 2017a):

$$
P_{\mathrm{DS}_{i j} \mid \mathrm{EDP}}= \begin{cases}1-F_{\mathrm{DS}_{i 1}}(\mathrm{EDP}) \cdot F_{\mathrm{DS}_{i 1}}(\mathrm{GP}) & (j=0 \text {, i.e., no damage }) \\ F_{\mathrm{DS}_{i j}}(\mathrm{EDP}) \cdot F_{\mathrm{DS}_{i j}}(\mathrm{GP})-F_{\mathrm{DS}_{i(j+1)}}(\mathrm{EDP}) \cdot F_{\mathrm{DS}_{i(j+1)}}(\mathrm{GP}) & (1 \leq j<n) \\ F_{\mathrm{DS}_{i j}}(\mathrm{EDP}) \cdot F_{\mathrm{DS}_{i j}}(\mathrm{GP}) & (j=n)\end{cases}
$$

where $F_{\mathrm{DS}_{i j}}(\mathrm{EDP})$ is fragility curve (=lognormal cumulative distribution function, exceedance probability) for the $i$ th component being in the $j$ th damage state conditioned on an $\mathrm{EDP}=e d p ; F_{\mathrm{DS}}(\mathrm{GP})$ is cumulative distribution function for the $i$ th component being in the 
$j$ th damage state conditioned on a geometric parameter GP $=g p$. This is essentially a factor to modify the $F_{\mathrm{DS}_{i j}}(\mathrm{EDP})$ and depends on the database compiled by Lignos and Karamanci (2013). The $P_{D \mid \mathrm{IM}, \mathrm{NC}}$ in Eq. (1) is obtained by the following equation:

$$
P_{D \mid \mathrm{IM}, \mathrm{NC}}=\int_{0}^{\infty} P_{D \mid \mathrm{RSDR}} f_{\mathrm{RSDR} \mid \mathrm{IM}} d \mathrm{RSDR}
$$

where $f_{\mathrm{RSDR} \mid \mathrm{IM}}$ is probability density function of the maximum residual drift ratio along the height of the building given an IM=im; $P_{D \mid \text { RSDR }}$ is probability of having to demolish the building conditioned on the maximum residual story drift ratio (RSDR) along the height of the building, which is modeled by lognormal distribution with a median $\mu_{\mathrm{DIRSDR}}=0.015$ radians and a $\log$ arithmic standard deviation $\beta_{\ln D \mid \mathrm{RSDR}}=0.3$ based on Ramirez and Miranda (2012). The $P_{C \mid \mathrm{IM}}$ in Eq. (1) is obtained by the following equation:

$$
P_{C \mid \mathrm{IM}}=\int_{0}^{I M} \frac{1}{s \beta \sqrt{2 \pi}} \exp \left[-\frac{\left(\ln s-\ln I M_{\mathrm{COL}, 50}\right)^{2}}{2 \beta^{2}}\right] d s
$$

where $\beta$ is a record-to-record variability of collapse uncertainty and $I M_{\mathrm{COL}, 50}$ is the median collapse intensity. $\beta$ and $I M_{\mathrm{COL}, 50}$ were computed based on Baker (2015). Note that in this approach, repair cost uncertainty (Yang et al., 2009; FEMA, 2018) is not accounted for. Note also that when there is no damage $(j=0)$, the cost factor $\left(=\mu_{L_{i j} \mid \mathrm{DS}_{i j}}\right)$ becomes zero $(=0)$, as noted in the Table in Appendix A. Thus, the inside product of Eq. (2) becomes zero when $j=0$. For this case, the top line in Eq. (3) can be omitted, as in Eq. (7) in Bradley et al. (2008). Note that if the cost uncertainty is accounted for, the $\mu_{L_{i j} \mid \mathrm{Ds}_{i j}}$ will have distribution, and depending on the sampling of distributions, they may become $\mu_{L_{i j} \mid \mathrm{DS}_{i j}} \neq 0$ even when $j=0$.

The results of calculation from Eq. (1) are integrated with seismic hazard curves to obtain expected annual loss $(E A L)$ as:

$$
E A L=\int_{0}^{\infty} \mu_{L_{\mathrm{T}} \mid \mathrm{IM}}\left|\frac{d \lambda_{\mathrm{IM}}}{d I M}\right| d I M
$$

where $\lambda_{\mathrm{IM}}$ is mean annual frequency of exceeding particular seismic intensity measure.

The above loss assessment procedure is implemented in MATLAB (version 9.1.0; The MathWorks, Inc. 2016) and the results are presented in the following sections. Source code and associated documentation are available on an online repository at https://github.com/ shkma/LossAssessment [last accessed: 05.Feburary.2021].

\section{Structures and isolation systems considered}

The 6-story seismically isolated and non-isolated steel buildings in Kitayama and Constantinou (2018a, b; 2019a, b) were considered. The original design of the seismically isolated building was presented in SEAOC Volume 5 Seismic Design Manual (SEAOC 2014) and McVitty and Constantinou (2015). The total seismic weight of the buildings when seismically isolated is $53,670 \mathrm{kN}$. When non-isolated, the weight is $45,285 \mathrm{kN}$. The buildings were assumed to be located on soil class D in San Francisco, CA (Latitude $37.783^{\circ}$, 
Longitude $\left.-122.392^{\circ}\right)$ with Risk-Targeted Maximum Considered Earthquake $\left(\mathrm{MCE}_{\mathrm{R}}\right.$; ASCE/SEI 7-16 2017) spectral acceleration values of $S_{\mathrm{MS}}=1.5 \mathrm{~g}$ and $S_{\mathrm{M} 1}=0.9 \mathrm{~g}$. For the Design Earthquake (DE; ASCE 2017), the parameters are $S_{\mathrm{DS}}=1.0 \mathrm{~g}$ and $S_{\mathrm{D} 1}=0.6 \mathrm{~g}$. All floors are classified for office occupancy (Risk Category II; ASCE/SEI 7-16 2017). The seismic force resisting frames for the isolated buildings were designed as follows: (a) per minimum criteria for $R_{\mathrm{I}}=2.0$ for the $\mathrm{MCE}_{\mathrm{R}}$ and (b) for $R_{\mathrm{I}}=1.0$ for the $\mathrm{MCE}_{\mathrm{R}}$ (per ASCE/ SEI 7-16). The comparable non-isolated building was designed based on Sect. 12.8.4.2 in ASCE/SEI 7-16 2017. Also, comparable non-isolated structures were designed with $R=6$, $\Omega_{0}=2, C_{\mathrm{d}}=5$ for the SCBF and with $R=8, \Omega_{0}=3, C_{\mathrm{d}}=5.5$ for the SMF. Note that the Sect. 17.5.4.2 of ASCE/SEI 7-16 (2017) specifies that the $R_{\mathrm{I}}$ factor for the seismically isolated superstructure shall be three-eighths of the value of $R$ given in Table 12.2-1, with a maximum value not greater than 2.0 and a minimum value not less than 1.0. The data from the results of seismic response analysis in Kitayama and Constantinou (2018a, b; 2019a, b), in terms of peak floor acceleration, peak and residual story drift ratio and probability of collapse, are used in this study. The member section properties and other details in the design of buildings can be found in Kitayama and Constantinou (2018a, b).

\section{Component fragility curves}

In calculating Eq. (3), the information of component fragility curves for components that are dependent and are not dependent on the geometric parameters, $F_{\mathrm{DS}_{i j}}(\mathrm{EDP})$ and $F_{\mathrm{DS}_{i j}}(\mathrm{GP})$, respectively, are used. This fragility information is expressed as median value $\left(=\mu_{\mathrm{EDP}}\right)$ and dispersion factor $\left(=\beta_{\mathrm{lnEDP}}\right.$; lognormal standard deviation $)$. Values of $\mu_{\mathrm{EDP}}$ and $\beta_{\mathrm{lnEDP}}$ for computing $F_{\mathrm{DS}_{i j}}(\mathrm{EDP})$ are summarized in Appendix A with the information of repair cost parameter $\mu_{L_{i j} \mid \mathrm{DS}_{i j}}$ for each component and damage state. Also, the values of $\mu_{\mathrm{GP}}$ and $\beta_{\mathrm{lnGP}}$ for computing $F_{\mathrm{DS}_{i j}}(\mathrm{GP})$ are summarized in Appendix B. The information in Appendix B is from Lignos and Karamanci (2013). Note that for buildings with SMFs, the dependence of geometric parameters on component fragility curves is not considered thus $F_{\mathrm{DS}_{i j}}(\mathrm{GP})$ in Eq. (3) is replaced with unity.

\section{Total replacement cost of the buildings}

Based on the studies of Thiel (1986), Mayes et al. (1990), Pyle et al. (1993), and Charleson and Allaf (2012), the cost differential between the seismically isolated and non-isolated buildings is the sum of the followings:

(i) Increased cost of the seismic isolation bearings and structural support systems;

(ii) Increased cost to allow for architectural accommodation of isolator displacement;

(iii) Increased cost to construct moat retaining wall around the entire perimeter of the building;

(iv) Savings by designing the isolated superstructure to a lower force level;

(v) Savings by reducing the number of bracings for some or all mechanical (non-structural components) systems; and

(vi) Increased cost of design services. 
Based on Ryan et al. (2010), the increased costs for i. to iii. above are estimated to be $883 \mathrm{USD} / \mathrm{m}^{2}$ (=82 USD $/ \mathrm{ft}^{2}$ ). This study considers four different types of seismic isolation systems for buildings with SCBF and SMF, as listed in Table 1. Those are triple friction pendulum (TFP; Fenz and Constantinou 2008) - the size of these bearings were determined based on the minimum requirement per ASCE/SEI 7-16 (ASCE 2017) without moat wall (TFP-1); TFP with moat wall at the onset of hardening regime (TFP-1, with moat wall); TFP with larger displacement capacity without moat wall (TFP-3); and double concave friction pendulum bearing (DC; Fenz and Constantinou 2006) with minimum required size per ASCE/SEI 7-16 (ASCE 2017) without moat wall (DC-1). The details of selected seismic isolation bearings are available in Kitayama and Constantinou (2018a, b; 2019a, b).

Construction of moat wall increases the cost. Based on the study by Ryan et al. (2010), the unit cost of constructing moat wall (with moat cover) costs $98 \mathrm{USD} / \mathrm{m}^{2}$ (=9.06 USD/ $\mathrm{ft}^{2}$ ). The single floor area of building is calculated to be $1756 \mathrm{~m}^{2} /$ floor for all buildings considered in this study (see Fig. 1 for building geometry). Thus, when the moat wall is not constructed, a total of (approximately) $98 \mathrm{USD} / \mathrm{m}^{2} \times 1756 \mathrm{~m}^{2}=171,234$ USD is discounted. Also, when the larger size isolators are used (TFP-3 instead of TFP-1), it was assumed that the cost for seismic isolation system increases by $5 \%$ (from the cost of TFP1 ), based on the reported costs of conventional isolators that are in the thousands of dollars (Konstantinidis and Kelly 2012; Ahmad et al. 2020). Note that the difference in the costs when using different seismic isolation bearings (TFP or DC) was not considered in this study (i.e., the costs for TFP and DC were assumed to be the same).

Since the isolated buildings with braced frames (especially the ones designed by $R_{\mathrm{I}}=2$ ) use smaller structural braces (i.e., smaller Hollow Structural Section or HSS braces) than the non-isolated buildings, some cost savings should be considered. This saving is estimated by the numbers of stories (in this case, braces at 1st and 2nd stories), quantities (=144 in total), and median cost of braces corresponding to $\operatorname{DS}_{i 3}$ ("Round HSS") in Appendix A (=47,882USD for non-isolated; 37,014USD for isolated) as: $\frac{2}{6} \cdot 144 \cdot(47,882-37,014)=521,664$ USD. Alternatively, one may compute the cost savings of structural elements based on the assumed weight of materials (ex. 4000USD/ton for steel, Ryan et al. 2010).

Thiel (1986) reported that the cost of bracing mechanical systems to meet the California Hospital Code is approximately $22-43 \mathrm{USD} / \mathrm{m}^{2}\left(=2-4 \mathrm{USD} / \mathrm{ft}^{2}\right)$. This implies that the cost saving by using reduced number of braces for mechanical systems when seismic isolation is used is not negligible for hospital building. This study examined office buildings, and it is assumed that there is much less mechanical bracing in the structures, thus this cost saving ("v.") is not considered in this study. Also, the increased cost of design service ("vi." above) for seismically isolated buildings is ignored in this study due to the unavailability of this information. Note that elements of seismic isolation systems are considered strong enough so that they will not have any damage (i.e., no repair action is needed for seismic isolation systems). Thus, the fragility and repair cost parameters for seismic isolation systems are not developed in this study.

The total replacement cost of the non-isolated buildings with SCBF and SMF are estimated by assuming that the square meter costs of buildings with SCBF and SMF are $1,880 \mathrm{USD} / \mathrm{m}^{2}$ and 2,690 USD $/ \mathrm{m}^{2}$, respectively, based on Hwang and Lignos (2017a; b). The total replacement cost for seismically isolated building is calculated by adding and subtracting the increased and saved costs calculated above ("i-vi") from the total replacement cost of non-isolated buildings. Table 1 summarizes replacement costs for all 


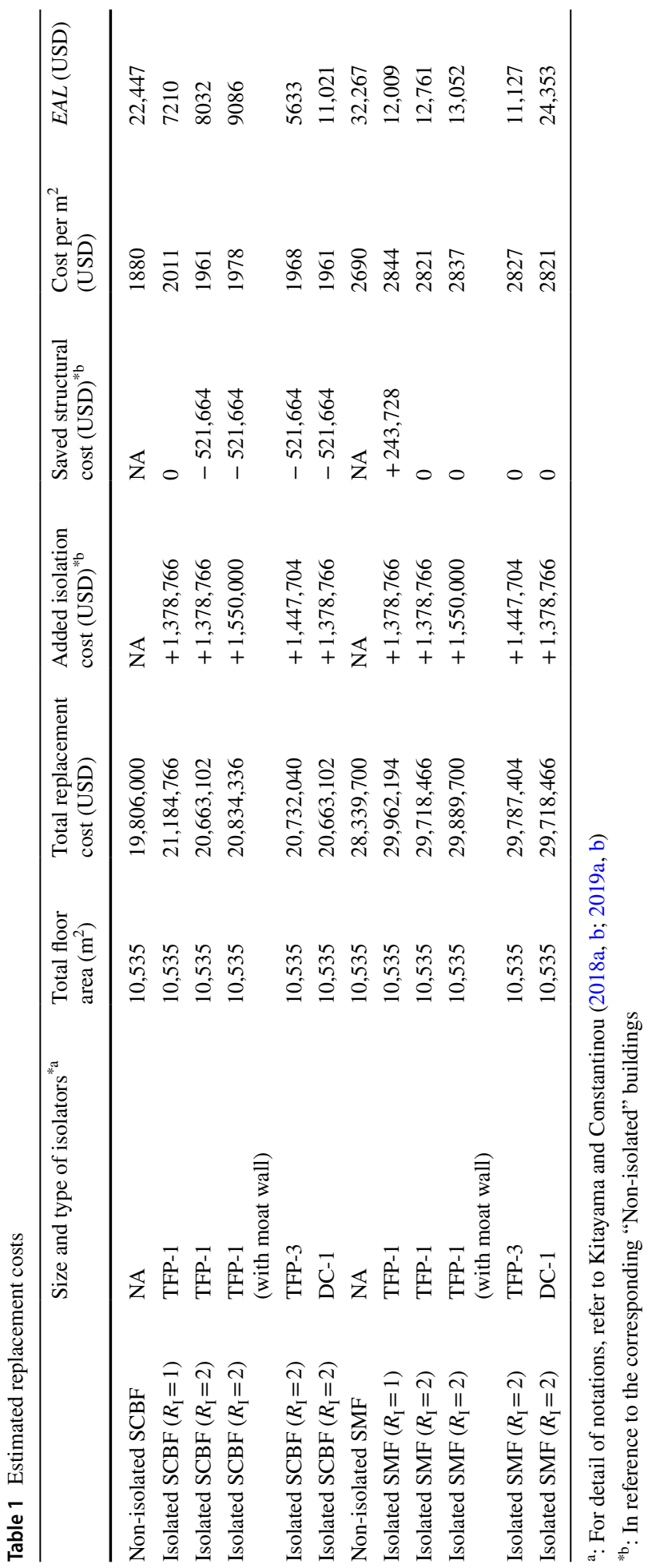


buildings. The estimated replacement costs are consistent with the recent previous studies (Ryan et al. 2010; Terzic et al. 2012).

\section{Results and discussion of seismic loss assessment}

This section provides results of seismic loss assessment. The calculation of Eq. (6) needs seismic hazard data, which are obtained for the site (Latitude $37.783^{\circ}$, Longitude $-122.392^{\circ}$ ) from USGS website (https://earthquake.usgs.gov/hazards/interactive/ [last accessed 4.Oct.2020]). See Fig. 3 for the seismic hazard curves used in this study. For more information, see Kitayama and Constantinou (2018a, 2019a).

\subsection{Loss vulnerability curves}

Figure 4 presents loss vulnerability curves for the selected cases in Table 1 . These figures show the relationship between intensity of ground motions (i.e., return period in this study) and mean of total seismic losses $\left(=\mu_{L_{\mathrm{T}} \mid \mathrm{IM}}\right.$, see Eq. (1)) normalized by total replacement cost (see Table 1). The use of return period for horizontal axis of vulnerability curves, instead of other intensity measures used in other studies, such as spectral acceleration at the structural fundamental period, $S a\left(T_{1}\right)$ (Ramirez et al. 2012; Hwang and Lignos 2017a, b), enables direct comparisons between vulnerability curves of different structural systems that have different $T_{1}$.

Note in case of the seismically isolated buildings, the return periods correspond to the spectral acceleration at the effective period of vibration, $T_{M}$ (Sect. 17 in ASCE 2017). The values of spectral accelerations are used as an intensity measure when integrating the vulnerability curves with seismic hazard curves to obtain expected annual loss $(E A L)$ in Eq. (6).

The comparisons of vulnerability curves between non-isolated (Fig. 4a, b) and isolated structures (Fig. 4c, d, e, f) indicate that isolated structures can mitigate seismic loss caused by frequent seismic events (small return periods). Comparisons of vulnerability curves between TFP with moat walls and DC without moat wall indicate that the seismic loss of seismically isolated buildings with DC systems are mostly resulted from collapse. Earlier studies by first author (Kitayama and Constantinou 2018a, b; 2019a, b) presented that the collapse of buildings with DC isolation systems without moat wall were caused by collapse of seismic isolation bearings led by excessive isolator displacement. As shown in Fig. 4(e) and (f), the vulnerability curves of collapse and total loss are almost identical.

Fig. 3 Seismic hazard curves for buildings studied

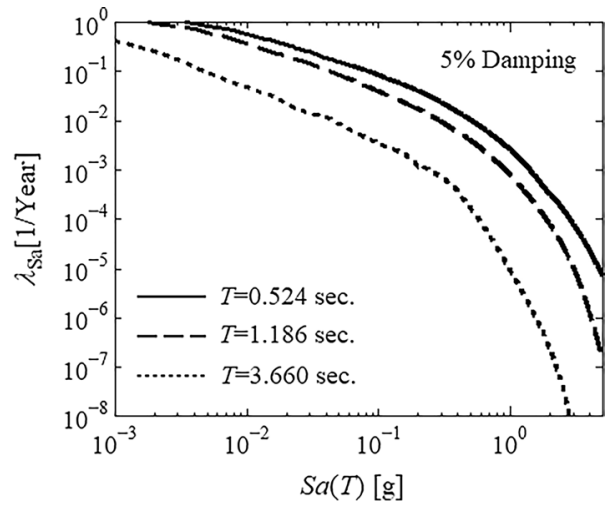



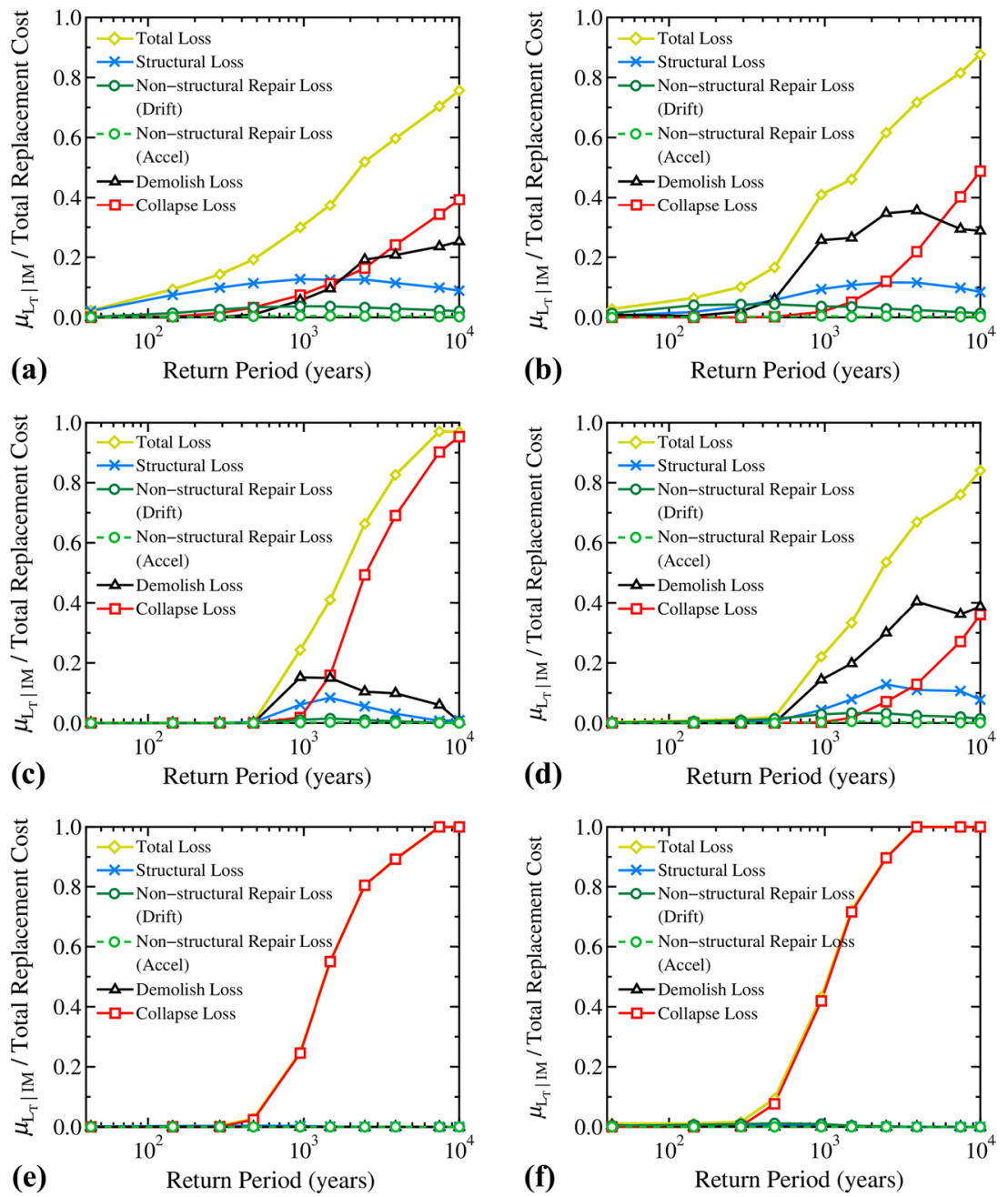

Fig. 4 Loss vulnerability curves of selected structural systems: a Non-isolated SCBF; b Non-isolated SMF; c Isolated SCBF designed with $R_{\mathrm{I}}=2$, with TFP and with moat wall; $\mathbf{d}$ Isolated SMF designed with $R_{\mathrm{I}}=2$, with TFP and with moat wall; e Isolated SCBF designed with $R_{\mathrm{I}}=2$, with DC and without moat wall; f Isolated SMF designed with $R_{\mathrm{I}}=2$, with $\mathrm{DC}$ and without moat wall

It is seen from Fig. 4(a) that for non-isolated SCBF, the loss from damage to structural components contribute largely under the lower intensity (= small return period) earthquakes. This is because the considered buildings with SCBF have a large number of braces in the seismic force resisting frames (see Fig. 1). Also, it is seen from Fig. 4b for nonisolated SMF, contribution of demolition loss is significant. This observation is consistent with the previous studies of non-isolated steel buildings (Hwang and Lignos, 2017a, b). 


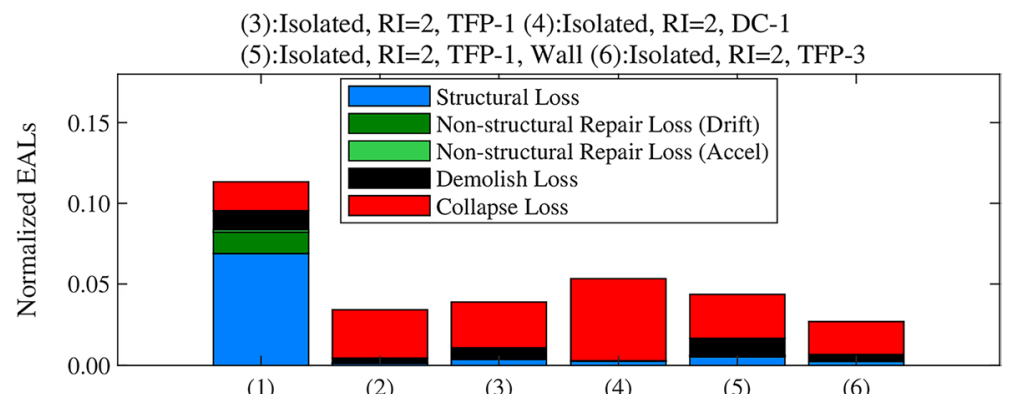

(1)

(2)

(3)

(4)

(5)

(6)

Buildings with SCBFs

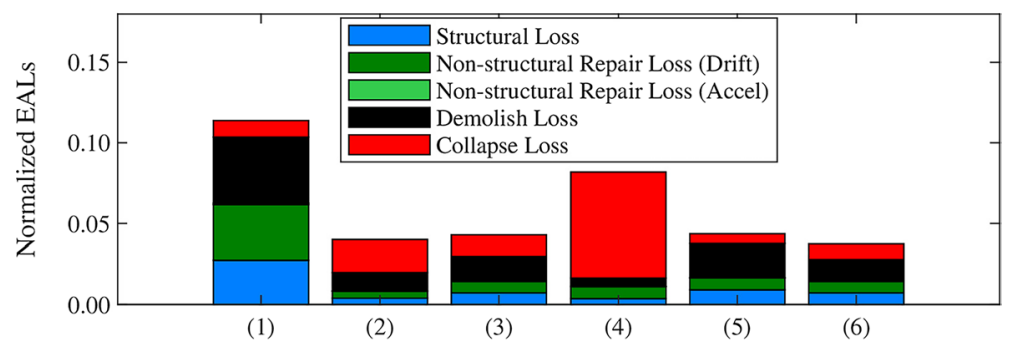

Buildings with SMFs

Fig. 5 Normalized expected annual losses for non-isolated and isolated steel frame buildings

\subsection{Expected annual loss}

Figure 5 presents the expected annual loss $(E A L)$ of all cases in Table 1, which were calculated from Eq. (6) and the information presented in Fig. 4. It is seen from the figure that the normalized $E A L$ for all the isolated buildings are smaller than the corresponding nonisolated buildings. For non-isolated buildings with SCBFs, the largest contribution to the $E A L$ is structural repair loss that is caused by the peak story drift. For isolated buildings with SCBFs, the collapse of buildings are the major contributor to the total EALs. For nonisolated buildings with SMFs, the largest contribution to the EAL is demolition loss that is caused by the residual story drift. This is also seen for the isolated buildings with SMFs. When DC bearings are used in seismic isolation system and moat wall is not used, the contribution of collapse is the largest loss among other losses for both buildings with SCBFs and SMFs. This is because when DC bearings are used in the seismic isolation systems, the damage to the superstructures is mitigated by the reduced floor acceleration and reduced story drift (Kitayama and Constantinou, 2018a, 2019a). 


\subsection{Effect of ground motion selection and scaling on the results of seismic loss assessment}

In the previous studies of seismic loss assessment of buildings, researchers used different ways of selection and scaling of ground motions for seismic response analysis. For example, Bradley et al. (2008), Ramirez and Miranda (2012), Ramirez et al. (2012), Dimopoulos et al. (2016), Sani et al. (2017) and Nikellis et al. (2019) used Incremental Dynamic Analysis (IDA; Vamvatsikos and Cornell 2002) to obtain EDP. The ground motion records used in these IDAs have large magnitudes and peak ground accelerations that may cause collapse of buildings and such records are scaled to represent frequent earthquake event (using small scale factors) and to represent rare earthquake event (using large scale factors). Thus, such analysis may not be suitable for seismic assessment of buildings which examines building performance under frequent to rare earthquake events as the ground motion records are not representative of frequent earthquake events. By recognizing that the collapse fragility curves obtained from IDA does not account for spectral shape effect (Baker and Cornell 2006), some researchers (Hwang and Lignos 2017a, b) modified the median values of spectral accelerations at the collapse of buildings (i.e., median collapse capacities) by multiplying factors (such factors have values that are usually larger than 1) based on Haselton et al. (2011) to consider spectral shape effect. However, since such modification only adjusts the values of $P_{\mathrm{CIIM}}$ in Eq. (1), it may not improve the seismic loss evaluation in terms of total value of $E A L$. Recent study by Elkady et al. (2018) computed earthquake induced loss of eight story buildings with steel moment frames using Conditional Spectrum approach based on Lin et al. (2013) that is similar to the approach used in the previous sections in this paper. Since the selection and scaling of the ground motions for seismic response analysis are the first major steps of loss assessment process (Krawinkler 2002), it is of interest to know the effect of using different approaches of selection and scaling of ground motions on the computed values of EAL. In this study, two additional approaches are compared with the Conditional Spectra approach that were presented in the previous sections: (i) IDA without adjustment of collapse fragility curves for spectral shape effect, and (ii) IDA with adjustment of collapse fragility curves based on Haselton et al. (2011) to consider spectral shape (hereafter, "SS") effect. The procedure of how the collapse fragility curves are adjusted for spectral shape effect is detailed in Kitayama and Constantinou (2018a). Note that the record set used for IDA is the far-field record set in FEMA P-695 (2009) with acceleration records of peak ground acceleration larger than $0.2 \mathrm{~g}$ and magnitude larger than 6.5. This set of ground motions was commonly used in the previous seismic loss assessment studies (Ramirez and Miranda 2012; Ramirez et al. 2012; Dimopoulos et al. 2016; Nikellis et al. 2019; etc.). Figure 6 summarizes both IDA approach and Conditional Spectra approach for selection and scaling of ground motions. The detailed information of both approaches is available in Kitayama and Constantinou (2018a).

Figure 7 presents the normalized EALs for non-isolated and seismically isolated steel frame buildings. Note that when the EDPs were obtained from IDA and the spectral shape effect was ignored for computing collapse fragility curves (i.e., without adjustment for collapse capacity or $P_{\mathrm{CIIM}}$ in Eq. (1)), it is denoted as "IDA w/o. SS adjustment." Similarly, when the EDPs were obtained from IDA and the collapse fragility curves were adjusted by the spectral shape factor (per Haselton et al., 2011), it is denoted as "IDA w. SS adjustment." By comparing the total normalized EALs between 


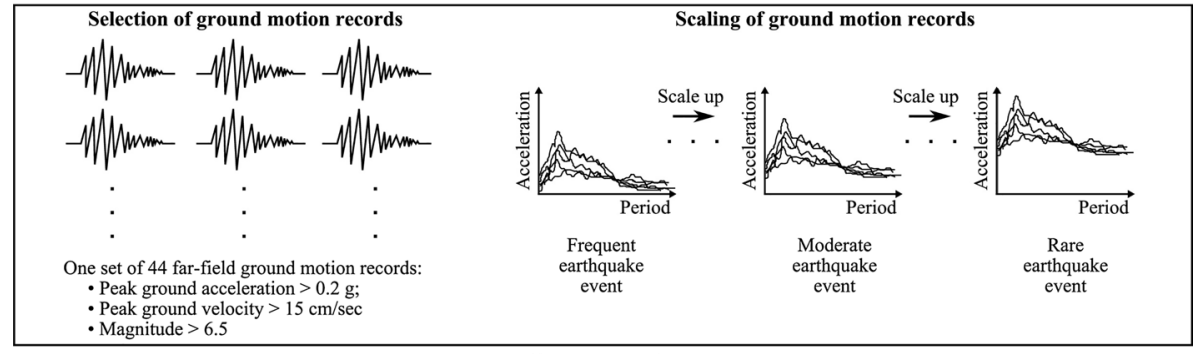

IDA approach

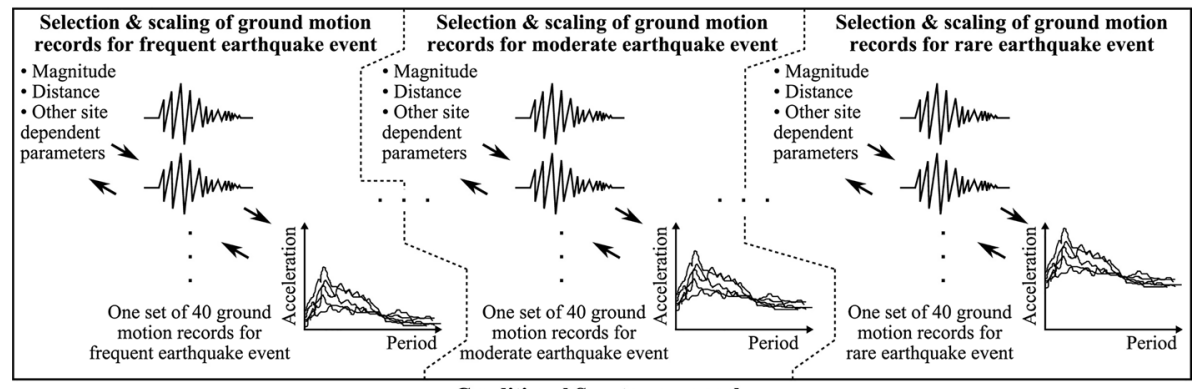

Conditional Spectra approach

Fig. 6 Summary of IDA approach and Conditional Spectra approaches

(1):Non-isolated (2):Isolated, RI=1, TFP-1

(3):Isolated, RI=2, TFP-1 (4):Isolated, RI=2, DC-1

(5):Isolated, RI=2, TFP-1, Wall (6):Isolated, RI=2, TFP-3

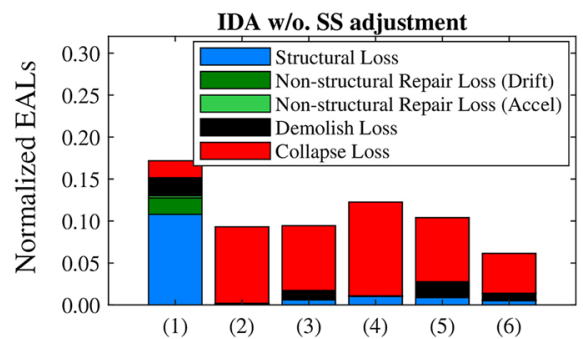

Buildings with SCBFs

IDA w/o. SS adjustment

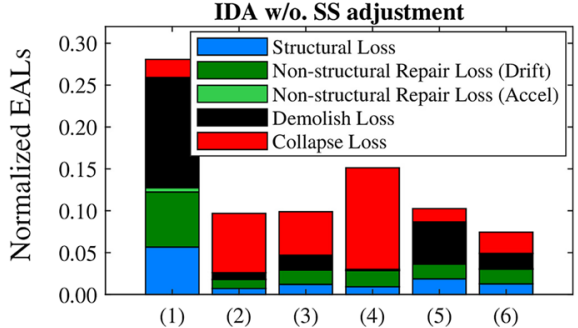

Buildings with SMFs
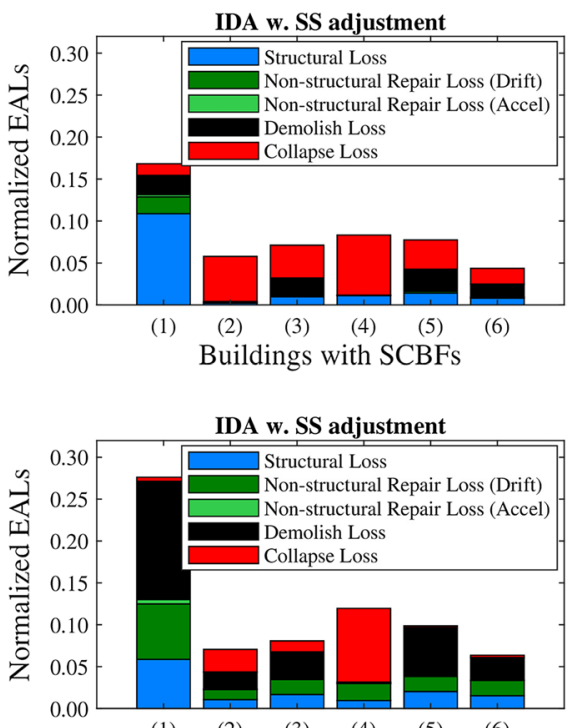

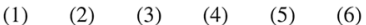

Buildings with SMFs

Fig. 7 Normalized expected annual losses for non-isolated and isolated steel frame buildings obtained from IDA for cases with and without spectral shape (SS) effect 
Figs. 5 and 7, there are clear differences between the values computed from Conditional Spectra approach (NIST 2011; Lin et al. 2013; see Fig. 5) and IDA approach (with and without SS effect, in Fig. 7). The total normalized EALs for both non-isolated and isolated buildings with SCBFs calculated from IDA approaches (in Fig. 7) are about twice of those from Conditional Spectra approach (in Fig. 5). The total normalized EALs for both non-isolated and isolated buildings with SMFs calculated from IDA approach (in Fig. 7) are more than twice of those from Conditional Spectra approach (in Fig. 5). By looking at the disaggregation of the total loss to five different losses (structural loss, non-structural repair losses, demolition loss and collapse loss), it is seen that while total loss are different from different approaches (i.e., Conditional spectra approach, IDA w/o. SS adjustment and IDA w. SS adjustment), the contributions to total losses from each of five losses (= each of five normalized losses divided by normalized total losses) are almost same.

When comparing the results between "IDA w/o. SS adjustment" and "IDA w. SS adjustment" in Fig. 7, it is seen that the consideration of SS effect reduces the seismic loss from collapse in all structures. The effect of SS is minor for non-isolated buildings with both SCBFs and SMFs because the contribution of collapse to the total loss is small for non-isolated buildings. This is in contrast with the results of collapse performance in terms of collapse probability conditioned at the Maximum Considered Earthquake $\left(\mathrm{MCE}_{\mathrm{R}}\right)$, in which SS effect made the large difference in the calculated values of probabilities of collapse at $\mathrm{MCE}_{\mathrm{R}}$ (probabilities of collapse were 6.3 and $3.4 \%$ when SS effect was not considered and considered, respectively, for buildings with SCBFs; probabilities of collapse were 0.87 and $0.02 \%$ when SS effect was not considered and considered, respectively, for buildings with SMFs; see Tables 3 and 5 in Kitayama and Constantinou 2019b). The effect of SS on the calculated total loss for seismically isolated buildings is more significant than those of non-isolated buildings because the ratio of losses computed from collapse in the seismically isolated buildings are larger than those in non-isolated buildings.

Table 2 Total EAL for studied cases from IDA approach with and without spectral shape adjustment

\begin{tabular}{|c|c|c|c|}
\hline & \multirow[t]{2}{*}{ Size and type of isolators ${ }^{* a}$} & \multicolumn{2}{|l|}{$E A L(\mathrm{USD})$} \\
\hline & & $\begin{array}{l}\text { IDA w/o. SS adjust- } \\
\text { ment }\end{array}$ & $\begin{array}{l}\text { IDA w. SS } \\
\text { adjustment }\end{array}$ \\
\hline Non-isolated SCBF & NA & 34,015 & 33,313 \\
\hline Isolated $\operatorname{SCBF}\left(R_{I}=1\right)$ & TFP-1 & 19,731 & 12,256 \\
\hline Isolated $\operatorname{SCBF}\left(R_{I}=2\right)$ & TFP-1 & 19,509 & 14,711 \\
\hline Isolated SCBF $\left(R_{I}=2\right)$ & TFP-1 (with moat wall) & 21,666 & 16,145 \\
\hline Isolated $\operatorname{SCBF}\left(R_{I}=2\right)$ & TFP-3 & 12,729 & 9,052 \\
\hline Isolated $\operatorname{SCBF}\left(R_{I}=2\right)$ & DC-1 & 25,338 & 17,209 \\
\hline Non-isolated SMF & NA & 79,590 & 78,296 \\
\hline Isolated SMRF $\left(R_{I}=1\right)$ & TFP-1 & 29,024 & 21,165 \\
\hline Isolated SMRF $\left(R_{I}=2\right)$ & TFP-1 & 29,386 & 24,020 \\
\hline Isolated SMRF $\left(R_{I}=2\right)$ & TFP-1 (with moat wall) & 30,677 & 29,497 \\
\hline Isolated $\operatorname{SMBF}\left(R_{I}=2\right)$ & TFP-3 & 22,193 & 18,969 \\
\hline Isolated $\operatorname{SMBF}\left(R_{I}=2\right)$ & DC-1 & 44,998 & 35,544 \\
\hline
\end{tabular}

$*_{\mathrm{a}}$ : For detail of notations, please refer to Kitayama and Constantinou (2018a, b; 2019a, b) 
Table 2 presents the results of calculated total $E A L$ for all studied cases for different ground motion selection and scaling approaches. Comparisons of EALs (in USD) between Tables 1 and 2 suggest that the Conditional Spectra approach (in Table 1) computes the EALs that are about half of EALs computed from IDA approach (in Table 2) for most structural systems considered in this study. Since the Conditional Spectra approach provides more accurate results by selecting and scaling all the ground motions for appropriate spectral shapes and for different intensities, the results of EALs obtained from IDA approach may be considered as over-conservative.

\section{Limitations of this study}

This paper offered a comprehensive investigation of seismic loss for seismically isolated and non-isolated steel buildings. However, a number of limitations of the present study should be pointed out. Such limitations may provide the basis for further research, which are listed as follow:

- While this study did not use vertical ground motions, the full-scale testing of seismically isolated buildings in E-Defense facility demonstrated that the vertical ground motions might cause damage to acceleration sensitive non-structural components and contents in the seismically isolated buildings (Furukawa et al. 2013).

- While this study considered structures with SCBFs and SMFs as superstructures on the seismic isolation systems, structural designers may use the Intermediate Moment Resisting Frames (IMRF) and Ordinary Concentric Braced Frames (OCBF) for moment frames and braced frames, respectively, on the seismic isolation systems, because those are more cost-effective structural systems than SMF and SCBF (Ryan et al. 2010; Sayani et al. 2011; Terzic et al. 2012; Masroor and Mosqueda 2015; Cutfielf et al. 2016).

- While the IDA was used with a simple IM of $S a\left(T_{1}\right)$ and a set of far-field ground motions from FEMA (2009), there are many more options (Kohrangi et al. 2020). Also, the use of Conditional Spectra with $S a\left(T_{1}\right)$ is not a panacea, and it may have issues of its own. It is certainly a better option versus IDA with a random far-field record set. Such concern was discussed more in detail for non-isolated buildings in Kohrangi et al. (2016).

- Cost-benefit analysis (Bradley et al. 2008; Dimopoulos et al. 2016; Ahmad et al. 2019) was not conducted in this paper. Future study may investigate how much is saved by constructing seismically isolated buildings (in comparison with non-isolated buildings) through the initial investment. The data presented in this paper may be used in such studies.

- The life cycle seismic performance assessment investigated in this paper focused on calculation of the seismic losses that arise from the repair effort needed to return a damaged building to its undamaged state. Other types of seismic losses, such as due to business interruption during structural and non-structural repair, and building closure (downtime) might also contribute to total seismic losses (Comerio 2006; Mitrani-Reiser 2007), however, such studies were left for future investigation.

- This study focused on the seismic loss assessment of seismically isolated buildings designed for far-field ground motions. Future investigations may address the seismic 
loss of seismically isolated buildings designed for sites within $3 \mathrm{mi}(5 \mathrm{~km})$ of the active fault that controls the hazard.

Also, the height, weight and shape of a building as well as the seismicity of the area may influence the results of loss assessment (Charleson and Allaf 2012; Molina Hutt et al. 2016). Although considerations of these might change the presented results in this paper, these are the limitation of this study that are worthy of future investigation.

\section{Conclusions}

This paper presented seismic loss assessment of seismically isolated and comparable non-isolated steel framed buildings. The study considered six-story office buildings located in California that were designed by the latest seismic design standard, ASCE/ SEI 7-16 (ASCE 2017). The different strength of isolated buildings, different sizes of seismic isolation bearings, and different types of seismic isolation systems were considered in the loss assessment. The Conditional Spectra approach (NIST 2011; Lin et al. 2013) was used for selection and scaling of seismic ground motions. The study also investigated the effect of using more common approach for selection and scaling of seismic ground motion records (i.e., IDA approach) on the results of seismic loss assessment. The main findings are summarized as follows:

1. As far as the specific structural configuration, specific occupancy type and specific location are considered, seismically isolated buildings can reduce the expected annual seismic loss by about half or less than half in comparisons with non-isolated buildings. This finding was true when both Conditional Spectra approach and more commonly used Incremental Dynamic Analysis approach with FEMA P-695 far-field ground motion set were used.

2. The seismic loss due to the damage to structural elements was the major contributors to the total seismic loss in the non-isolated buildings with SCBFs in terms of expected annual loss. On the other hand, the seismic loss due to the collapse was the major contributors to the total seismic loss in the seismically isolated buildings with SCBF.

3. The seismic loss due to the damage to drift sensitive non-structural components and loss due to the demolition were the major contributors to the total seismic loss in the non-isolated buildings with SMFs, in terms of expected annual loss. On the other hand, the seismic loss due to the collapse and the demolition were the major contributors to the total seismic loss in the seismically isolated buildings with SMF.

4. When the DC isolators were used for seismic isolation systems, the contribution of collapse loss to the total loss was large.

5. The most cost-effective seismic isolation systems were buildings designed by $R_{I}=2$ (i.e., minimum required strength of superstructures per ASCE/SEI 7-16 standard) and with the size triple friction pendulum isolators with the displacement capacity of 1.5 times of minimum required by ASCE/SEI 7-16 (i.e., TFP-3 or displacement capacity of $1.5 D_{\mathrm{M}}$ - see Kitayama and Constantinou 2018a, b), in terms of expected annual losses. This was true regardless of framing systems used (SCBF or SMF) and regardless of approaches of selection and scaling of ground motions for seismic response analysis.

6. When IDA approaches (Vamvatsikos and Cornell 2002) with and without spectral shape correction and with far-field ground motion set in FEMA (2009) were used, the total 
expected annual loss became twice or more than twice of those calculated by Conditional Spectra approach, depending on the structural systems considered. Note that the IDA results can be fairly inconsistent from record set to record set and site to site, thus more research is needed to generalize the information.

7. When the spectral shape effect on the collapse fragility curve was accounted for based on Haselton et al. (2011), the expected annual loss (EAL) of seismically isolated buildings were reduced. However, it had relatively less effect on the results of seismic loss of non-isolated buildings.

\section{Appendix 1}

Median values and dispersion factors of component fragility curves $F_{D S_{i j}}(E D P)$ and repair cost parameters for buildings with SCBF or SMF (Unless noted, data are from Hwang and Lignos 2017a).

\begin{tabular}{|c|c|c|c|c|c|c|c|c|}
\hline \multirow[t]{2}{*}{ Category } & \multirow[t]{2}{*}{$\begin{array}{l}\text { Component } \\
\text { description }\end{array}$} & \multirow{2}{*}{$\begin{array}{l}\text { Damage } \\
\text { States } \\
\text { (DS) }\end{array}$} & \multirow[t]{2}{*}{ Unit } & \multicolumn{3}{|c|}{$\begin{array}{l}\text { Fragility } \\
\text { parameters }\end{array}$} & \multirow[b]{2}{*}{$\begin{array}{l}\mu_{L_{i j} \mid \mathrm{DS}_{i i}} \\
\text { (USD }^{*}{ }^{2}, \mathrm{VI}\end{array}$} & \multirow[t]{2}{*}{$\begin{array}{l}\text { Quantity } \\
\text { (total) }\end{array}$} \\
\hline & & & & EDP & $\mu_{\mathrm{EDP}}$ & $\beta_{\text {lnEDP }}$ & & \\
\hline \multirow{14}{*}{$\begin{array}{l}\text { Structural } \\
\text { compo- } \\
\text { nents }\end{array}$} & $\begin{array}{l}\text { Column base } \\
(\mathrm{W}<223 \mathrm{~kg} / \mathrm{m})\end{array}$ & $\mathrm{DS}_{i 1}$ & $\mathrm{EA}^{* \mathrm{I}}$ & $\mathrm{SDR}^{*}{ }^{* I I}$ & 0.04 & 0.40 & 19,224 & 16 \\
\hline & & $\mathrm{DS}_{i 2}$ & & & 0.07 & 0.40 & 27,263 & \\
\hline & & $\mathrm{DS}_{i 3}$ & & & 0.10 & 0.40 & 32,423 & \\
\hline & $\begin{array}{l}\text { Column base } \\
\begin{array}{l}(223 \mathrm{~kg} / \mathrm{m}<\mathrm{W} \\
\quad \leq 446 \mathrm{~kg} / \mathrm{m})\end{array}\end{array}$ & $\mathrm{DS}_{i 1}$ & EA & SDR & 0.04 & 0.40 & 20,082 & \\
\hline & & $\mathrm{DS}_{i 2}$ & & & 0.07 & 0.40 & 29,395 & \\
\hline & & $\mathrm{DS}_{i 3}$ & & & 0.10 & 0.40 & 36,657 & \\
\hline & $\begin{array}{l}\text { Column base } \\
(446 \mathrm{~kg} / \mathrm{m}<\mathrm{W})\end{array}$ & $\mathrm{DS}_{i 1}$ & EA & SDR & 0.04 & 0.40 & 21,363 & \\
\hline & & $\mathrm{DS}_{i 2}$ & & & 0.07 & 0.40 & 32,567 & \\
\hline & & $\mathrm{DS}_{i 3}$ & & & 0.10 & 0.40 & 41,890 & \\
\hline & $\begin{array}{l}\text { Column splices } \\
(\mathrm{W}<223 \mathrm{~kg} / \mathrm{m})\end{array}$ & $\mathrm{DS}_{i 1}$ & EA & SDR & 0.04 & 0.40 & 9,446 & 64 \\
\hline & & $\mathrm{DS}_{i 2}$ & & & 0.07 & 0.40 & 11,246 & \\
\hline & & $\mathrm{DS}_{i 3}$ & & & 0.10 & 0.40 & 38,473 & \\
\hline & $\begin{array}{l}\text { Column splices } \\
(223 \mathrm{~kg} / \mathrm{m} \\
\quad<\mathrm{W} \leq 446 \mathrm{~kg} / \mathrm{m})\end{array}$ & $\mathrm{DS}_{i 1}$ & EA & SDR & 0.04 & 0.40 & 10,246 & \\
\hline & & $\mathrm{DS}_{i 2}$ & & & 0.07 & 0.40 & 13,012 & \\
\hline
\end{tabular}




\begin{tabular}{|c|c|c|c|c|c|c|}
\hline Category & $\begin{array}{l}\text { Component } \\
\text { description }\end{array}$ & $\begin{array}{l}\text { Damage } \\
\text { States }\end{array}$ & Unit & $\begin{array}{l}\text { Fragility } \\
\text { parameters }\end{array}$ & Repair cost & $\begin{array}{l}\text { Quantity } \\
\text { (total) }\end{array}$ \\
\hline
\end{tabular}

\begin{tabular}{|c|c|c|c|c|c|c|c|}
\hline & & & EDP & $\mu_{\mathrm{EDP}}$ & $\beta_{\text {lnEDP }}$ & $\begin{array}{l}\mu_{L_{i j} \mid \mathrm{DS}_{i j}} \\
\left(\mathrm{USD}^{*} \mathrm{~V}, \mathrm{VI}\right)\end{array}$ & \\
\hline & $\mathrm{DS}_{i 3}$ & & & 0.10 & 0.40 & 42,533 & \\
\hline \multirow[t]{3}{*}{$\begin{array}{l}\text { Column splices } \\
(446 \mathrm{~kg} / \mathrm{m}<\mathrm{W})\end{array}$} & $\mathrm{DS}_{i 1}$ & EA & SDR & 0.04 & 0.40 & 11,446 & \\
\hline & $\mathrm{DS}_{i 2}$ & & & 0.07 & 0.40 & 14,812 & \\
\hline & $\mathrm{DS}_{i 3}$ & & & 0.10 & 0.40 & 47,594 & \\
\hline \multirow[t]{3}{*}{$\begin{array}{l}\text { Column } \\
(\leq \mathrm{W} 27)^{* \mathrm{VII}}\end{array}$} & $\mathrm{DS}_{i 1}$ & EA & SDR & 0.03 & 0.30 & 16,033 & 192 \\
\hline & $\mathrm{DS}_{i 2}$ & & & 0.04 & 0.30 & 25,933 & \\
\hline & $\mathrm{DS}_{i 3}$ & & & 0.05 & 0.30 & 25,933 & \\
\hline \multirow[t]{3}{*}{$\begin{array}{l}\text { Column } \\
(\geq \mathrm{W} 27)^{* \mathrm{VII}}\end{array}$} & $\mathrm{DS}_{i 1}$ & EA & SDR & 0.03 & 0.30 & 17,033 & \\
\hline & $\mathrm{DS}_{i 2}$ & & & 0.04 & 0.30 & 28,433 & \\
\hline & $\mathrm{DS}_{i 3}$ & & & 0.05 & 0.30 & 28,433 & \\
\hline \multirow[t]{3}{*}{$\begin{array}{l}\text { Round HSS } \\
\text { (Weight }<60 \mathrm{~kg} / \mathrm{m}) \\
\text { (SCBF only) }\end{array}$} & $\mathrm{DS}_{i 1}$ & EA & SDR & 0.0041 & 0.51 & 29,983 & 144 \\
\hline & $\mathrm{DS}_{i 2}$ & & & 0.0096 & 0.45 & 37,014 & \\
\hline & $\mathrm{DS}_{i 3}$ & & & 0.0275 & 0.51 & 37,014 & \\
\hline \multirow[t]{3}{*}{$\begin{array}{l}\text { Round HSS } \\
(61 \mathrm{~kg} / \mathrm{m}<\text { Weight } \\
\quad<147 \mathrm{~kg} / \mathrm{m}) \\
\text { (SCBF only) }{ }^{* 1}\end{array}$} & $\mathrm{DS}_{i 1}$ & EA & SDR & 0.0041 & 0.51 & 29,983 & \\
\hline & $\mathrm{DS}_{i 2}$ & & & 0.0096 & 0.45 & 47,115 & \\
\hline & $\mathrm{DS}_{i 3}$ & & & 0.0275 & 0.51 & 47,882 & \\
\hline \multirow[t]{3}{*}{$\begin{array}{l}\text { Moment connection } \\
\text { (one-sided } \leq \mathrm{W} 27 \text {, } \\
\text { SMF only) }\end{array}$} & $\mathrm{DS}_{i 1}$ & EA & SDR & 0.03 & 0.30 & 16,033 & 48 \\
\hline & $\mathrm{DS}_{i 2}$ & & & 0.04 & 0.30 & 25,933 & \\
\hline & $\mathrm{DS}_{i 3}$ & & & 0.05 & 0.30 & 25,933 & \\
\hline \multirow[t]{3}{*}{$\begin{array}{l}\text { Moment connection } \\
\text { (one-sided } \geq \mathrm{W} 27 \text {, } \\
\text { SMF only) }\end{array}$} & $\mathrm{DS}_{i 1}$ & EA & SDR & 0.03 & 0.30 & 17,033 & \\
\hline & $\mathrm{DS}_{i 2}$ & & & 0.04 & 0.30 & 28,433 & \\
\hline & $\mathrm{DS}_{i 3}$ & & & 0.05 & 0.30 & 28,433 & \\
\hline $\begin{array}{l}\text { Moment connection } \\
\text { (two-sided } \leq \mathrm{W} 27 \text {, } \\
\text { SMF only) }\end{array}$ & $\mathrm{DS}_{i 1}$ & EA & SDR & 0.03 & 0.30 & 30,400 & 48 \\
\hline
\end{tabular}




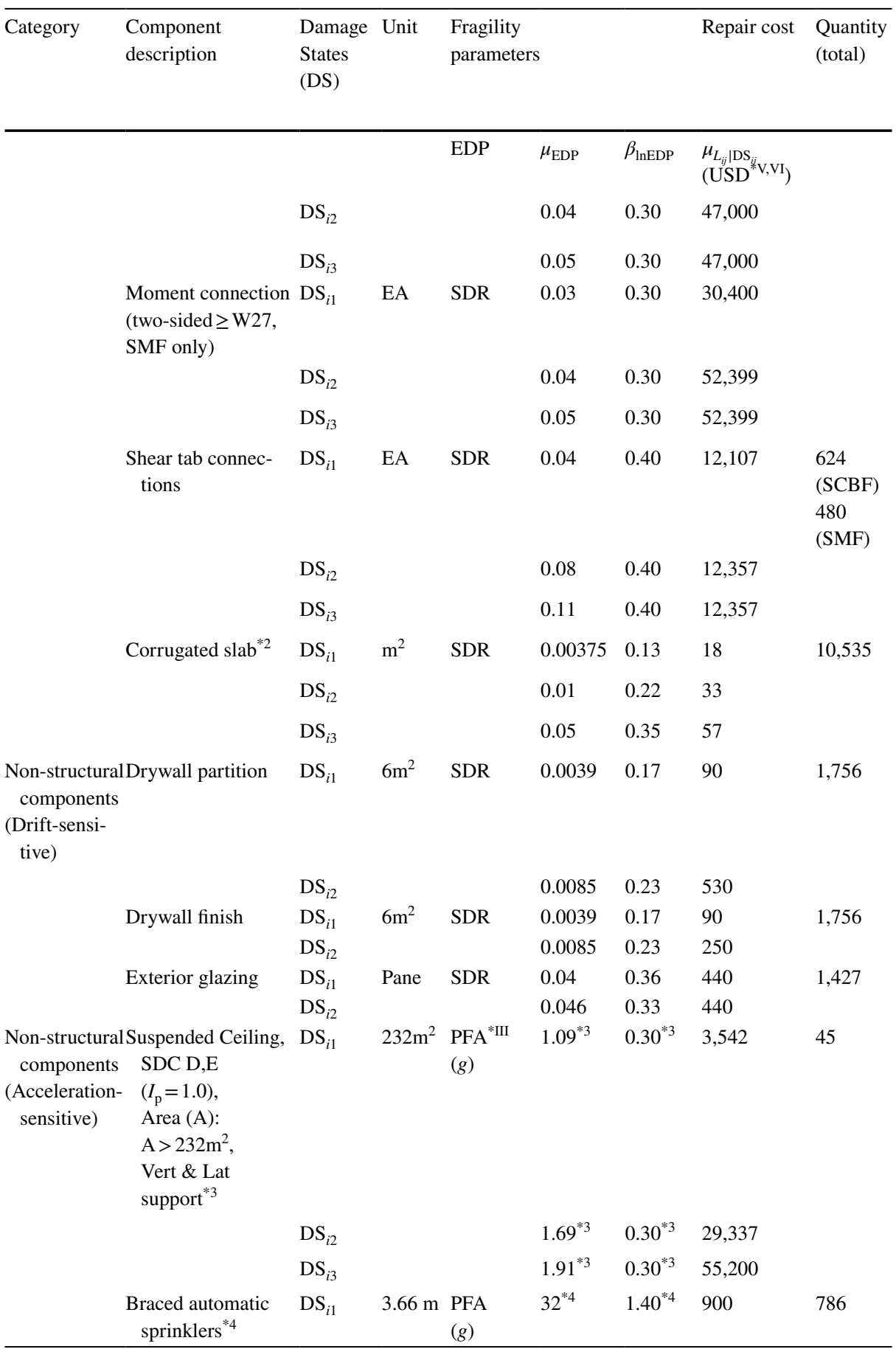




\begin{tabular}{|c|c|c|c|c|c|c|c|c|}
\hline \multirow[t]{3}{*}{ Category } & \multirow[t]{2}{*}{$\begin{array}{l}\text { Component } \\
\text { description }\end{array}$} & \multirow{2}{*}{$\begin{array}{l}\text { Damage } \\
\text { States } \\
\text { (DS) }\end{array}$} & \multirow[t]{2}{*}{ Unit } & \multicolumn{3}{|c|}{$\begin{array}{l}\text { Fragility } \\
\text { parameters }\end{array}$} & Repair cost & \multirow[t]{2}{*}{$\begin{array}{l}\text { Quantity } \\
\text { (total) }\end{array}$} \\
\hline & & & & EDP & $\mu_{\mathrm{EDP}}$ & $\beta_{\text {lnEDP }}$ & $\begin{array}{l}\mu_{L_{i j} \mid \mathrm{DS}_{i j}} \\
\left.\text { (USD }^{*} \mathrm{~V}, \mathrm{VI}\right)\end{array}$ & \\
\hline & Elevator & $\mathrm{DS}_{i 1}$ & EA & $\begin{array}{l}\text { PGA }^{* I V} \\
(g)\end{array}$ & 0.50 & 0.28 & 868 & 2 \\
\hline
\end{tabular}

*I: EA = Each component; *II: SDR = Story drift ratio; *III: PFA = Peak floor acceleration; *IV: PGA = Peak ground acceleration; $* \mathrm{~V}$ : USD $=$ United States Dollar; $* \mathrm{VI}: \mu_{L_{i 0} \mid \mathrm{DS}_{i 0}}=0$; $* \mathrm{VII}$ : Note: The section properties of the gravity frames (columns and beams) are determined based on the previous studies (SEAOC 2014; McVitty and Constantinou 2015). The following gravity columns are considered: W $12 \times 96, \mathrm{~W} 12 \times 58$ and $\mathrm{W} 12 \times 35$ for $1^{\text {st }}$ and 2 nd stories, 3rd and 4th stories and 5th and 6th stories, respectively. Also, the following gravity beams are considered: W $33 \times 118$ for the $1^{\text {st }}$ floor (isolated buildings only) and W $21 \times 44$ for other floors (both isolated and non-isolated buildings).; *1: From Lignos and Karamanci (2013).; *2: From Hwang et al. (2015).; *3: From FEMA (2018),; *4: From Appendix B.5.1. in Porter and Kiremidjian (2001).

\section{Appendix 2}

Median values and dispersion factors for cumulative distribution function $F_{D S_{i j}}(E D P)$ (Lignos and Karamanci 2013).

\begin{tabular}{llll}
\hline Assembly description & & $\begin{array}{l}\text { Fragility parameters } \\
(\mathrm{GP}=K L / r)\end{array}$ & \\
& Damage state & $\beta_{\text {InKL/r }}$ & 0.46 \\
\hline Round HSS brace & $\mathrm{DS}_{i 1}$ & 63.6 & 0.45 \\
& $\mathrm{DS}_{i 2}$ & 66.1 & 0.40 \\
& $\mathrm{DS}_{i 3}$ & 68.9 & \\
\hline
\end{tabular}

Acknowledgements The writers acknowledge the advice and support from SUNY Distinguished Professor Michael C. Constantinou in the Department of Civil, Structural and Environmental Engineering at the University at Buffalo, State University of New York.

Funding The author(s) received no financial support for the research, authorship, and/or publication of this article.

Availability of data and material The data that support the findings of this study are available from the corresponding author upon reasonable request.

Code availability Some or all data, models, or code generated or used during the study are available in a repository or online in accordance with funder data retention policies (https://github.com/shkma/LossAssess ment [last accessed 5.February.2021]).

\section{Declarations}

Conflict of interest Shoma Kitayama and Huseyin Cilsalar declare that they have no conflict of interest/ competing interest. 
Ethical approval Shoma Kitayama and Huseyin Cilsalar declare that they approve all ethics requirements specified by publisher.

Consent to participate Shoma Kitayama and Huseyin Cilsalar declare that they consent that they participate in crafting this manuscript.

Consent for publication Shoma Kitayama and Huseyin Cilsalar declare that they consent the manuscript will be published upon acceptance.

Open Access This article is licensed under a Creative Commons Attribution 4.0 International License, which permits use, sharing, adaptation, distribution and reproduction in any medium or format, as long as you give appropriate credit to the original author(s) and the source, provide a link to the Creative Commons licence, and indicate if changes were made. The images or other third party material in this article are included in the article's Creative Commons licence, unless indicated otherwise in a credit line to the material. If material is not included in the article's Creative Commons licence and your intended use is not permitted by statutory regulation or exceeds the permitted use, you will need to obtain permission directly from the copyright holder. To view a copy of this licence, visit http://creativecommons.org/licenses/by/4.0/.

\section{References}

Adam JM, Parisi F, Sagaseta J, Lu X (2018) Research and practice on progressive collapse and robustness of building structures in the 21st century. Eng Struct 173(15):122-149. https://doi.org/10.1016/j.engst ruct.2018.06.082

Ahmad N, Akbar J, Rizwan M, Alam B, Khan AN, Lateef A (2019) Haunch retrofitting technique for seismic upgrading deficient RC frames. Bull Earthq Eng 17:3895-3932. https://doi.org/10.1007/ s10518-019-00638-9

Ahmad N, Shakeel H, Masoudi M (2020) Design and development of low-cost HDRBs seismic isolation of structures. Bull Earthq Eng 18:1107-1138. https://doi.org/10.1007/s10518-019-00742-w

ASCE/SEI 7 (2010) Minimum design loads for buildings and other structures. Am Soc Civil Eng. https:// doi.org/10.1061/9780784412916

ASCE/SEI 7 (2017) Minimum design loads and associated criteria for buildings and other structures. Am Soc Civil Eng. https://doi.org/10.1061/9780784414248

Baker JW (2011) Conditional mean spectrum: tool for ground-motion selection. J Struct Eng 137(3):332344. https://doi.org/10.1061/(ASCE)ST.1943-541X.0000215

Baker JW (2015) Efficient analytical fragility function fitting using dynamic structural analysis. Earthq Spectra 31(1):579-599. https://doi.org/10.1193/021113EQS025M

Baker JW, Cornell CA (2006) Spectral shape, epsilon and record selection. Eng Struct Dyn 35(9):10771095. https://doi.org/10.1002/eqe.571

Bao Y, Becker TC, Sone T, Hamaguchi H (2018) To limit forces or displacements: collapse study of steel frames isolated by sliding bearings with and without restraining rims. Soil Dyn Earthq Eng 112:203124. https://doi.org/10.1016/j.soildyn.2018.05.006

Baradaran Shoraka M, Yang TY, Elwood KJ (2013) Seismic loss estimation of non-ductile reinforced concrete buildings. Earthq Eng Struct Dyn 42(2):297-310. https://doi.org/10.1002/eqe.2213

Bradley BA, Dhakal RP, Cubrinovski M, MacRae GA (2008) Seismic loss estimation for efficient decision making. In: Proceeding of 2008 NZSEE conference. Paper number 32. New Zealand Society for Earthquake Engineering. Bayview Wairakei Resort, Wairakei, NZ

Charleson AW, Allaf N (2012) Costs of base-isolation and earthquake insurance in New Zealand. In: Proceeding of 2012 NZSEE conference. New Zealand Society for Earthquake Engineering, Paper number 41

Cilsalar H (2019) Development and validation of a seismic isolation system for lightweight residential construction. In: Ph.D. Dissertation, Department of Civil, Structural and Environmental Engineering, University at Buffalo, The State University of New York, Buffalo, N.Y., U.S.A

Cilsalar H, Constantinou MC (2020) Parametric study of seismic collapse performance of lightweight buildings with spherical deformable rolling isolation system. Bull Earthq Eng 18:1475-1498. https://doi. org/10.1007/s10518-019-00753-7

Comerio MC (2006) Estimating downtime in loss modeling. Earthq Spectra 22(2):349-365. https://doi.org/ $10.1193 / 1.2191017$ 
Cutfield M, Ryan K, Ma Q (2016) Comparative life cycle analysis of conventional and base-isolated buildings. Earthq Spectra 32(1):323-343. https://doi.org/10.1193/032414EQS040M

Dimopoulos A, Tzimas AS, Karavasilis TL, Vamvatsikos D (2016) Probabilistic economic seismic loss estimation in steel buildings using post-tensioned moment-resisting frames and viscous dampers. Earthq Eng Struct Dyn 45(11):1725-1741. https://doi.org/10.1002/eqe.2722

Dong Y, Frangopol DM (2016) Performance-based seismic assessment of conventional and base-isolated steel buildings including environmental impact and resilience. Earthq Eng Struct Dyn 45(4):739-756. https://doi.org/10.1002/eqe.2682

Elkady A, Ghimire S, Lignos DG (2018) Fragility curves for wide-flange steel columns and implications for building-specific earthquake-induced loss assessment. Earthq Spectra 34(3):1405-1429. https://doi. org/10.1193/122017EQS260M

Erduran E, Dao ND, Ryan KL (2011) Comparative response assessment of minimally compliant low-rise conventional and base-isolated steel frames. Earthq Eng Struct Dyn 40(10):1123-1141. https://doi.org/ 10.1002/eqe. 1078

FEMA (2009) Quantification of building seismic performance factors. Report FEMA P-695. Washington DC, USA. Federal Emergency Management Agency

FEMA (2018) Seismic performance assessment of buildings: FEMA P-58 fragility specification. prepared by the applied technology council for the federal emergency management agency, Washington, DC. December. Third edition

Fenz DM, Constantinou MC (2006) Behaviour of the double concave friction pendulum bearing. Earthq Eng Struct Dyn 35(11):1403-1424. https://doi.org/10.1002/eqe.589

Fenz DM, Constantinou MC (2008) Spherical sliding isolation bearings with adaptive behavior: theory. Earthq Eng Struct Dyn 37(2):163-183. https://doi.org/10.1002/eqe.751

Furukawa S, Sato E, Shi Y, Becker T, Nakashima M (2013) Full-scale shaking table test of a base-isolated medical facility subjected to vertical motions. Earthq Eng Struct Dyn 42(13):1931-1949. https://doi.org/ 10.1002/eqe. 2305

Goda K, Lee CS, Hong HP (2010) Lifecycle cost-benefit analysis of isolated buildings. Struct Saf 32(1):52-63. https://doi.org/10.1016/j.strusafe.2009.06.002

Haselton CB, Baker JW, Liel AB, Deierlein GG (2011) Accounting for ground-motion spectral shape characteristics in structural collapse assessment through an adjustment for epsilon. J Struct Eng 137(3):332-344. https://doi.org/10.1061/(ASCE)ST.1943-541X.0000103

Hwang SH, Elkady A, Al Bardaweel S, Lignos DG (2015) Earthquake loss assessment of steel frame buildings designed in highly seismic regions. In: Papadrakakis M, Papadopoulos V, Plevris V (eds.) proceedings. COMPDYN 2015, 5th ECCOMAS thematic conference on computational methods in structural dynamics and earthquake engineering, Crete Island, Greece, 25-27

Hwang SH, Lignos DG (2017a) Effect of modeling assumptions on the earthquake-induced losses and collapse risk of steel-frame buildings with special concentrically braced frames. J Struct Eng 143(9):04017116. https://doi.org/10.1061/(ASCE)ST.1943-541X.0001851

Hwang SH, Lignos DG (2017b) Earthquake-induced loss assessment of steel frame buildings with special moment frames designed in highly seismic regions. Earthq Eng Struct Dyn 46(13):2141-2162. https://doi. org/10.1002/eqe.2898

Kikuchi M, Black CJ, Aiken ID (2008) On the response of yielding seismically isolated structures. Earthq Eng Struct Dyn 37(5):659-679. https://doi.org/10.1002/eqe.777

Kitayama S, Constantinou MC (2018b) Collapse performance of seismically isolated buildings designed by the procedures of ASCE/SEI 7. Eng Struct 164:243-258. https://doi.org/10.1016/j.engstruct.2018.03.008

Kitayama S, Constantinou MC (2019a) Probabilistic seismic performance assessment of seismically isolated buildings designed by the procedures of ASCE/SEI 7 and other enhanced criteria. Eng Struct 179:566582. https://doi.org/10.1016/j.engstruct.2018.11.014

Kitayama S, Constantinou MC (2019b) Effect of displacement restraint on the collapse performance of seismically isolated buildings. Bull Earthq Eng. https://doi.org/10.1007/s10518-019-00554-y

Kitayama S, Constantinou MC (2018a) "Seismic performance assessment of seismically isolated buildings designed by the procedures of ASCE/SEI 7.” Report MCEER-18-0004, University at Buffalo, Buffalo, NY

Kohrangi M, Vamvatsikos D, Bazzurro P (2016) Implications of intensity measure selection for seismic loss assessment of 3-D buildings. Earthq Spectra. https://doi.org/10.1193/112215EQS177M

Kohrangi M, Vamvatsikos D, Bazzurro P (2020) Multi-level conditional spectrum-based record selection for IDA. Earthq Spectra. https://doi.org/10.1177/8755293020919425

Konstantinidis D, Kelly JM (2012) "Two low-cost seismic isolation systems." In: $15^{\text {th }}$ World Conference on Earthquake Engineering, (15WCEE), Lisbon, Portugal, 24-28 
Krawinkler H (2002) A general approach to seismic performance assessment.” In: Proceeding of international conference on advances and new challenges in earthquake engineering research, Hong Kong. 3. 173-180

Lignos DG, Karamanci E (2013) Drift-based and dual-parameter fragility curves for concentrically braced frames in seismic regions. J Constr Steel Res 90:209-220. https://doi.org/10.1016/j.jcsr.2013.07.034

Lin T, Haselton CB, Baker JW (2013) Conditional spectrum-based ground motion selection. Part I: Hazard consistency for risk-based assessments. Earthq Eng Struct Eng 42(12):1847-1865. https://doi.org/10.1002/ eqe. 2301

Masroor A, Mosqueda G (2015) Assessing the collapse probability of base-isolated buildings considering pounding to moat walls using the FEMA P695 methodology. Earthq Spectra 31(4):2069-2086. https://doi. org/10.1193/092113EQS256M

The MathWorks, Inc. (2016) MATLAB version 9.1.0.441655 (R2016b). Natick, Massachusetts

Mayes RL, Jones LR, Kelly TE (1990) The economics of seismic isolation in buildings. Earthq Spectra. https:// doi.org/10.1193/1.1585567

Mayes R, Tam K, Weaver B, Wetzel N, Parker W, Brown A, Pietra D (2013) Performance based design of buildings to assess damage and downtime and implement a rating system. Bull N Z Soc Earthq Eng 46(1):40-55

McVitty WJ, Constantinou MC (2015) Property modification factors for seismic isolators: design guidance for buildings. MCEER-15-0005, Multidisciplinary Center for Earthquake Engineering Research, Buffalo, NY

Mitrani-Reiser J (2007) An ounce of prevention: probabilistic loss estimation for performance-based earthquake engineering. In: PhD Dissertation. California Institute of Technology. Pasadena. CA. http://resolver.calte ch.edu/CaltechETD:etd-05282007-233606

Molina HC, Almufti I, Willford M, Deierlein D (2016) Seismic loss and downtime assessment of existing tall steel-framed buildings and strategies for increased resilience. ASCE J Struct Eng 142(8):C4015005. https://doi.org/10.1061/(ASCE)ST.1943-541X.0001314

Nikellis A, Sett K, Whittaker AS (2019) Multihazard design and cost-benefit analysis of buildings with special moment-resisting steel frames. J Struct Eng 145(5):04019031. https://doi.org/10.1061/(ASCE)ST.1943541X.0002298

NIST (2011) Selecting and scaling earthquake ground motions for performing response-history analysis. NIST GCR 11-917-15. Technical Report, prepared by the NEHRP consultants joint venture for the National Institute of Standards and Technology: Gaithersburg, Maryland

Okada S, Takai N (2000) Classifications of structural types and damage patterns of buildings for earthquake field investigation. In: $12^{\text {th }}$ world conference on earthquake engineering. Auckland, New Zeland, 30 January - Friday 4 February 2000

Porter KA, Kiremidjian AS (2001) Assembly-based vulnerability of buildings and its uses in seismic performance evaluation and risk management decision-making. John A Blume Earthquake Engineering Center Technical Report 139. Stanford Digital Repository. Available at: http://purl.stanford.edu/qf102hx9901

Pyle SL, Janssen AG, Holmes WT, Kircher CA (1993) Life-cycle cost study for the State of California Justice Building. In: Proceedings of ATC-17-1 seminar on seismic isolation, passive energy dissipation, and active control. San Francisco, California, March 11-12, 1993. Volume 1: Seismic isolation systems. Applied Technology Council

Ramirez CM, Miranda E (2012) Significance of residual drifts in building earthquake loss estimation. Earthquake Eng Struct Dyn 41(11):1477-1493. https://doi.org/10.1002/eqe.2217

Ramirez CM, Liel AB, Mitrani Reiser J, Haselton CB, Spear AD, Steiner J, Deierlein GG, Miranda E (2012) Expected earthquake damage and repair costs in reinforced concrete frame buildings. Earthq Eng Struct Dynam 41(11):1455-1475. https://doi.org/10.1002/eqe.2216

Ryan KL, Sayani PJ, Dao ND, Abraik E, Baez YM (2010) Comparative life cycle analysis of conventional and base-isolated theme buildings. In: Proceedings of $9^{\text {th }}$ US National \& $10^{\text {th }}$ Canadian Conference on Earthquake Engineering. Toronto, Canada

Sani HP, Gholhaki M, Banazadeh M (2017) Seismic performance assessment of isolated low-rise steel structures based on loss estimation. J Perform Constr Facil 31(4):04017028. https://doi.org/10.1061/(ASCE) CF.1943-5509.0001028

Sayani PJ, Erduran E, Ryan KL (2011) Comparative response assessment of minimally compliant low-rise base-isolated and conventional steel moment-resisting frame buildings. J Struct Eng 137(10):1118-1131. https://doi.org/10.1061/(ASCE)ST.1943-541X.0000358

SEAOC, Structural Engineers Association of California (2014) 2012 IBC SEAOC structural/seismic design manual. volume 5: Examples for seismically isolated buildings and buildings with supplemental damping." Published January 2014

Shenton HW, Lin AN (1993) Relative performance of fixed-base and base-isolated concrete frames. J Struct Eng 119(10):2952-2968. https://doi.org/10.1061/(ASCE)0733-9445(1993)119:10(2952) 
State of California Seismic Safety Commission (1991) Policy on acceptable levels of earthquake risk in state buildings. Report No. SSC 91-1

Terzic V, Merrifield SK, Mahin SA (2012) Lifecycle cost comparisons for different structural systems designed for the same location. In: Proceedings of 15th world conference on earthquake engineering, 15WCEE. September, Lisbon, Portugal

Thiel CC (1986) Life cycle seismic cost considerations in structural system selection: Conventional versus base isolation design options. In: ATC-17. proceedings of a seminar and workshop on base isolation and passive energy dissipation. San Francisco, California. March 12-14, 1986. Applied Technology Council

Vamvatsikos D, Cornell CA (2002) Incremental dynamic analysis. Earthq Eng Struct Dyn 31(3):491-514. https://doi.org/10.1002/eqe.141

Yang TY, Moehle J, Kiureghian AD (2009) Seismic performance evaluation of facilities: methodology and implementation. J Struct Eng 135(10):1146-1154. https://doi.org/10.1061/(ASCE)0733-9445(2009)135: 10(1146)

Publisher's Note Springer Nature remains neutral with regard to jurisdictional claims in published maps and institutional affiliations. 